1 Brewerton DA, Caffrey M, Nicholls A, Walters D, Oates JK, James DCO. Reiter's disease and HLA-B27. Lancet 1973;ii:996-8.

2 Calin A. Reiter's syndrome. In: Kelley WW, Harris ED Jr, Ruddy S, Sledge CB, eds. Textbook of rheumatology. Philadelphia: Saunders, 1981:1033-46.

3 Keat A, Thomas B, Dixey J, Osborn M, Sonnex C, Taylor-Robinson D. Chlamydia trachomatis and reactive arthritis: the missing link. Lancet 1987;ii:72-4.

4 Lahesmaa-Rantala R, Granfors K, Isomäki H, Toivanen A. Yersinia specific immune complexes in the synovial fluid of patients with yersinia triggered reactive arthritis. Ann Rheum Dis 1987;46:510-4.

5 Konttinen YT, Nordström D, Bergroth V, Leirisalo-Repo M, Skrifvars B. Cell-mediated immune response in the diseased joints in patients with reactive arthritis. Scand $\mathcal{f}$ Immunol $1986 ; 23: 685-91$

(Accepted 14 March 1988)

IV Department of Medicine, Helsinki University Central Hospital, Unioninkatu 38, SF-00170, Finland

YRJÖ T KONTTINEN, MD, senior researcher

DAN C NORDSTROM, MD, research fellow

VILLE BERGROTH, MD, senior researcher

II Department of Medicine, Helsinki University Central Hospital, SF-00290, Finland

MARJATTA LEIRISALO-REPO, MD, senior researcher

Orthopaedic Hospital of the Invalid Foundation, Tenholantie 10, SF-00280, Finland

SEPPO SANTAVIRTA, MD, senior researcher

Correspondence to: Dr Konttinen.

\section{Variability in reviewing attenders at accident and emergency departments in England}

The yearly rate of new attendances at accident and emergency departments in England increased steadily between 1949 and 1984 from 89 to 218 per 1000 population, while the ratio of reattendances to new attendances (the reattendance rate) fell steadily from $1 \cdot 6$ to $0 \cdot 3$ (inter-regional range $0 \cdot 2-0 \cdot 4$ ). ${ }^{\text {' }}$ We examined the district rates of reattendance between 1974 and 1985 because an even wider range between districts would have policy implications for the delivery of primary care. annual reattendance rate and the time trend was $-0.37(\mathrm{p}<0.01){ }^{3}$ Thus the yearly reattendance rate in districts where the level of reattendance was high fell significantly more quickly than in districts where it was low.

\section{Comment}

The wide geographical variation in reviewing first attenders is surprising. Systematic undercounting is unlikely as the Department of Health and Social Security guidelines to regions define reattendance. Moreover, failure to count every visit would risk understating departmental workload and disadvantage any bid for resources. Certain accident and emergency departments may undertake specialty functions such as orthopaedics, so that their reattendances include orthopaedic outpatient visits, etc. Such departments are not performing the modern role planned for them. Differing diagnostic case mixes are another possible explanation. This would imply that certain departments were seeing patients with less severe conditions who in other areas might have been cared for by general practitioners. Accident and emergency departments are assumed to substitute for the normal delivery of primary care by general practitioners in socioeconomically deprived areas. ${ }^{45}$ Yet socioeconomic classification of the health districts failed to show that the deprived districts had higher reattendance rates. Nor were districts with extreme reattendance rates grouped in particular regions. Other demographic characteristics of first attenders, like age, may determine reattendance, but the most likely explanation is that accident and emergency departments differ widely in their medical policies for reviewing patients.

Most accident and emergency departments were reviewing patients less often. The size of the reductions, however, varied. Departments with higher reattendance rates showed greater declines. It may well be that the burgeoning demand for such services has outstripped supply and led to a reduction in the reattendance rate as full capacity is approached.

If all accident and emergency departments who reviewed patients more often than the national median reduced their follow up rate to the median the number of reattendances would decline by roughly 1 million. This might mean transferring some of the workload to general practice, however, not reducing it totally.

We thank Mr John Charlton and his colleagues in the Statistics and Research Division of the Department of Health and Social Security in London and the North Flyde Central Offices in Blackpool for providing the SH3 returns of accident and emergency attendances. The Medical Care Research Unit is supported by the Department of Health and Social Security and Trent Regional Health Authority.

Mean yearly reattendance rate at accident and emergency departments in English health districts 1974-85

\begin{tabular}{|c|c|c|c|c|c|c|c|c|c|c|c|}
\hline $\begin{array}{l}\text { Reattendance rate per new attendance } \\
\text { No of health districts }\end{array}$ & $\begin{array}{c}<0 \cdot 1 \\
6\end{array}$ & $\begin{array}{c}0 \cdot 1- \\
9\end{array}$ & $\begin{array}{c}0 \cdot 2- \\
32\end{array}$ & $\begin{array}{c}0 \cdot 3- \\
35\end{array}$ & $\begin{array}{c}0 \cdot 4- \\
43\end{array}$ & $\begin{array}{c}0.5- \\
35\end{array}$ & $\begin{array}{c}0 \cdot 6- \\
13\end{array}$ & $\begin{array}{c}0 \cdot 7- \\
10\end{array}$ & $\begin{array}{c}0 \cdot 8- \\
5\end{array}$ & $\begin{array}{c}0.9- \\
2\end{array}$ & $\begin{array}{c}1 \cdot 0-1 \cdot 09 \\
1\end{array}$ \\
\hline
\end{tabular}

\section{Methods and results}

Yearly numbers of new and total attendances at accident and emergency departments between 1974 and 1985 for each of the 191 English health districts existing in 1985 were provided by the Department of Health and Social Security. Reattendance numbers were calculated as the total attendances minus the new attendances. Where district boundaries had altered before 1985 attendances were reattributed from the original districts to the new districts, consistent with the 1985 boundaries. The socioeconomic state of health districts was classified according to the Office of Population Censuses and Surveys' cluster analysis of the 1981 census: high status, rural, town, city, local authority housing, or London. ${ }^{2}$

The means of the annual reattendance rates for $1974-85$ were used to represent the average levels of reattendance. They were distributed around a median of 0.44 (interquartile range 0.25 , table). There was a 26 -fold difference in range $(0 \cdot 04-1 \cdot 06)$. Socioeconomic classification and grouping of districts according to health region explained only $3 \%$ and $11 \%$ of this variation, respectively.

The simple linear regression coefficient of the rate against time indicated a significant $(p<0.05)$ falling trend in $133(70 \%)$ health districts. The median rate of change was 16 fewer reattendances per 1000 new attendances per year (range -113 to +16$)$. The Spearman rank correlation coefficient between the mean
1 Department of Health and Social Security. Health and personal social services statistics for England. 1972, 1976, 1986 Editions. London: Her Majesty's Stationery Office; 1973, 1977, 1987. 2 Craig JA. 1981 Socioeconomic classification of local and health authorities of Great Britain. London: Her Majesty's Stationery Office, 1985. (OPCS studies on medical and population subjects No 48 .

3 Gill JS, Zezulka AV, Beevers GD, Davies P. Relation between initial blood pressure and its fall with treatment. Lancet 1985; ; $567-9$.

4 Fairley J, Hewett WC. Survey of casualty departments in Greater London. Br Med f 1969;ii:375-7. 5 Weinerman ER, Ratner RS, Robbins A, Lavenhar MA. Determinants of use of hospital emergency services. Am f Pub Health 1966;56: 1037-56.

(Accepted 19 February 1988)

Medical Care Research Unit, Department of Community Medicine, University of Sheffield Medical School, Sheffield S10 2RX

PC MILNER, MRCP, lecturer

J P NICHOLL, MSC, senior statistician

B T WILLIAMS, FFCM, professor

Correspondence to: Dr Milner 